\title{
ANALISIS PENGARUH DPK, NPL, LDR, CAR DAN BI RATE TERHADAP PENYALURAN KREDIT PADA BANK PERKREDITAN RAKYAT DI KOTA BATAM
}

\section{ANALYSIS OF DPK, NPL, LDR, CAR AND BI RATE EFFECTS ON CREDIT DISTRIBUTION OF RURAL BANKS (BPR) IN BATAM CITY}

\author{
Clinton Kwan $\mathrm{Ng}^{1}$, Bornok Situmorang ${ }^{2}$ \\ ${ }^{1}$ Fakultas Bisnis, Universitas Universal \\ email: clintonkwanng@yahoo.com \\ 2 Fakultas Bisnis, Universitas Universal \\ email: bornoksitumorang@gmail.com
}

\begin{abstract}
ABSTRAK
Penelitian ini bertujuan untuk mengetahui pengaruh DPK, NPL, LDR, CAR \& BI Rate terhadap penyaluran kredit. Metode analisis yang digunakan dalam model penelitian ini adalah analisis deskriptif dan regresi linier berganda. Hasil penelitian ini menunjukkan bahwa DPK, CAR, LDR \& $\mathrm{BI}$ Rate memiliki pengaruh positif secara parsial terhadap penyaluran kredit dengan nilai signifikansi masing-masing sebesar $0.00,0.00,0.00 \& 0.034$ sedangkan NPL tidak memiliki pengaruh secara parsial terhadap penyaluran kredit dengan nilai signifikansi sebesar 0.075 dan memiliki arah koefisien yang negatif. Serta dari hasil uji secara simultan DPK, CAR, LDR, NPL \& $\mathrm{BI}$ Rate memiliki pengaruh secara bersamaan terhadap penyaluran kredit dengan nilai signifikansi sebesar 0.00 .

Kata Kunci: Penyaluran Kredit, Dana Pihak Ketiga, Non Performing Loan, Loan to Deposit Ratio, Capital Adequacy Ratio
\end{abstract}

\begin{abstract}
This research aims to study the effect of DPK, NPL, LDR, CAR \& BI Rate on lending. The analytical method used in this research model is descriptive analysis and multiple linear regression. The results of this study indicate that DPK, CAR, LDR \& BI Rate have a positive influence on lending with a significance value of respectively $0.00,0.00,0.00 \& 0.034$ while NPL does not have a partial relationship to the distribution credit with a significance value of 0.075 and has a negative coefficient direction. In addition, DPK, CAR, LDR, NPL \& BI rates have the same relationship to lending with a significance value of 0.00 .
\end{abstract}

Keywords: Credit Distribution, Third Party Funds, Non Performing Loans, Loans to Deposit Ratio, Capital Adequacy Ratio 


\section{PENDAHULAN}

Bank Perkreditan Rakyat (BPR) merupakan salah satu lembaga keuangan bank yang menghimpun dan menyalurkan dana kembali dalam bentuk pinjaman kepada masyarakat. Penyaluran kredit pada BPR mayoritas adalah pelaku Usaha Mikro Kecil Menengah (UMKM) atau masyarakat menengah ke bawah karena BPR dapat memberikan pelayanan prosedur yang lebih sederhana dan lokasi nya mudah di jangkau oleh masyarakat kecil, serta lebih mengutamakan hubungan baik dengan cara pendekatan personal dengan nasabah dan melakukan penyesuaian prosedur dalam memberikan pinjaman.

Namun kemajuan teknologi memberikan tantangan baru kepada BPR, karena muncul nya fintech dalam hal layanan pinjam meminjam uang berbasis teknologi informasi seperti Financial Technology Peer to Peer (P2P) lending. Hal tersebut mendorong Otoritas Jasa Keuangan (OJK) untuk mengupayakan konsolidasi pada BPR yang masih belum mampu memenuhi ketentuan modal inti minimum sesuai dengan Peraturan OJK (POJK) Nomor 5/POJK.03/2015 tentang Kewajiban Penyediaan Modal Minimum (KPMM), karena dengan konsolidasi tersebut BPR bisa memperkuat modal serta dapat memberikan volume pinjaman yang lebih besar, maka dalam pemenuhan persyaratan modal pada suatu bank mempunyai pengaruh besar kecil nya volume penyediaan pinjaman kepada masyarakat (Bridges et al., 2014). Apalagi dengan terpenuhi tingkat modal minimum yang baik maka BPR dapat memberikan volume pinjaman yang lebih besar dan dapat memastikan dana yang di miliki suatu bank cukup untuk mengantisipasi dari kerugian tak terduga atau guncangan yang merugikan (Abdul Karim, Hassan, Hassan, \& Mohamad, 2014). Dalam mengukur tingkat bagus atau tidak nya modal inti minimum dapat menggunakan rasio Capital Adequacy Ratio (CAR). Menurut Otoritas Jasa Keuangan, standar pada rasio $C A R$ atau KPMM yang di tetapkan yaitu minimum sebesar $12 \%$ (dua belas persen), maka bisa di katakan semakin besar nilai rasio CAR menunjukkan juga semakin baik kemampuan BPR dalam menghadapi kemungkinan risiko kerugian.

\section{LANDASAN TEORI}

\section{Kredit}

Kredit berasal dari bahasa latin yaitu credere atau trust yang berarti kepercayaan yang di berikan kreditur kepada debitur akan komitmen dalam kesepakatan pengembalian pinjaman yang telah di sepakati (Fahmi, 2014). Penyaluran kredit dapat di lihat dari total keseluruhan kredit yang di salurkan oleh bank kepada pihak yang meminjam berdasarkan komitmen atas kesepakatan pinjam-meminjam yang diharuskan untuk mengembalikan dana terutang dan bunga sesuai dengan jangka waktu yang di sepakati (Haryanto \& Widyarti, 2017).

\section{Dana Pihak Ketiga (DPK)}

Dana Pihak Ketiga (DPK) adalah sumber dana dari masyarakat baik dari individu maupun kelompok sebagai debitur yang di simpan dalam bentuk giro, tabungan dan deposito (Fahmi, 2014). Menurut Peraturan Bank Indonesia (PBI) No.15/7/PBI/2013, menjelaskan bahwa DPK merupakan kewajiban Bank kepada penduduk dan bukan penduduk dalam Rupiah dan valuta asing. Maka dapat disimpulkan bahwa DPK merupakan kewajiban berupa giro, tabungan dan deposito di bank terhadap masyarakat sebagai debitur dalam mata uang rupiah maupun asing. 


\section{Capital Adequacy Ratio (CAR)}

Kewajiban Penyediaan Modal Minimum atau Capital adequacy ratio merupakan istilah rasio yang di gunakan untuk mengukur kecukupan modal bank, yaitu kemampuan bank dalam pembiayaan aktivitas kegiatan usahanya dengan kepemilikan modal yang di miliki (Fahmi, 2014). Dalam POJK No.5/POJK.03/2015 mewajibkan BPR untuk menyediakan modal minimum atau CAR sebesar $12 \%$. Dengan kata lain, CAR adalah rasio perbankan untuk pengukuran kecukupan modal yang di miliki bank untuk membantu menunjang aktiva yang menghasilkan risiko, misalnya penyaluran kredit.

\section{Loan to Deposit Ratio (LDR)}

Loan to Deposit Ratio (LDR) merupakan rasio bank yang di gunakan untuk mengukur tingkat likuiditas dengan membandingkan jumlah kredit yang di salurkan dengan jumlah deposit yang di himpun dan dimiliki bank (Fahmi, 2014). LDR dapat memperlihatkan sejauh mana kemampuan suatu bank dalam membayar kembali dari penarikan dana debitur serta memperlihatkan sejauh mana kemampuan bank dalam mempergunakan dana hasil dari debitur untuk memberikan pinjaman (Adnana et al., 2016). Maka dalam penghimpunan dana dari masyarakat dan deposit yang di miliki oleh bank berkaitan sangat erat dengan pinjaman yang di berikan bank karena mencerminkan fungsi transformasi likuiditas. Dalam rasio $L D R$ menjadi indikator inti untuk risiko ketidakcocokan suatu likuiditas sebab rasio tersebut mengukur kecukupan pinjaman dengan pendanaan yang stabil (Van den End, 2016).

\section{Non Performing Loan (NPL)}

Non Performing Loan (NPL) merupakan di mana sejumlah pinjaman kredit oleh debitur yang mengalami gagal bayar atau tidak mampu mengembalikan pinjaman secara tepat waktu dan akan berdampak pada kinerja bank (Fahmi, 2014). NPL sangat penting karena secara agregat dapat mencerminkan kualitas kredit dari portofolio pinjaman sektor perbankan di suatu Negara (Ozili, 2019), maka munculnya NPL dalam jumlah yang besar dapat membuat bank kesulitan dalam menurunkan tingkat kesehatan bank.

Sedangkan menurut POJK No.15/POJK.03/2017, menyatakan kredit bermasalah atau NPL jumlah kredit yang memiliki kualitas kurang lancar, diragukan dan macet atau rasio kredit bermasalah secara neto lebih dari 5\% (lima persen) dari total kredit. Rasio NPL merupakan rasio yang di gunakan bank dalam mengukur risiko dari penyaluran kredit dengan membandingkan jumlah kredit macet dengan jumlah kredit yang di salurkan (Fahmi, 2014).

\section{BI Rate}

Suku bunga merupakan harga yang dibayarkan oleh pihak peminjam (debitur) kepada pihak yang meminjamkan (kreditur) atas pemakaian sumber daya selama periode waktu tertentu. Suku bunga tersebut terdiri dari dua yaitu, suku bunga rill dan suku bunga nominal. Suku bunga rill adalah pertumbuhan daya konsumsi selama periode pinjaman. Suku bunga nominal adalah sebaliknya, merupakan jumlah unit moneter yang harus dibayar per unit yang dipinjam, dan sebenarnya suku bunga pasar dari pinjaman (Situmorang, 2017). Bank Indonesia (BI) Rate merupakan suku bunga acuan yang di keluarkan menurut kebijakan Bank Indonesia. BI rate juga merupakan suatu tindakan operasi moneter yang di gunakan untuk mengelola likuiditas di pasar uang sehingga dapat mencapai tujuan dari sasaran kebijakan moneter (Haryanto \& Widyarti, 2017). Menurut Bank Indonesia, BI rate adalah suku bunga acuan yang dapat memperlihatkan sikap dari kebijakan moneter pada suatu negara yang di tetapkan oleh BI dan di publikasikan kepada publik. Penetapan respons (stance) kebijakan moneter dilakukan setiap bulan melalui 
mekanisme Rapat Dewan Gubernur (RDG) Bulanan dengan cakupan materi bulanan. Namun dalam memperkuat kerangka operasi kebijakan moneter dalam hal mengenai kebijakan suku bunga acuan, pada 19 agustus 2016 Bank Indonesia mengimplementasikan kebijakan suku bunga acuan baru yaitu BI 7-Day (Reverse) Repo Rate.

\section{Pengembangan Hipotesis \\ Pengaruh Dana Pihak Ketiga (DPK) terhadap Penyaluran Kredit}

Menurut (Fahmi, 2014) sumber dana yang di himpun dari masyarakat merupakan dana yang paling banyak di gunakan bank dalam penyaluran kredit yaitu mencapai $80 \%-90 \%$ dari seluruh dana yang di miliki bank. Dalam hasil penelitian (Adnana et al., 2016) menunjukkan bahwa peningkatan dana pihak ketiga akan membuat penyaluran kredit ikut meningkat.

Maka tingginya dana pihak ketiga yang di miliki bank menunjukkan bahwa bank memiliki dana yang lebih untuk di salurkan kepada masyarakat dalam bentuk kredit sehingga dapat hal tersebut dapat meningkatkan tingkat dana yang di salurkan oleh bank tersebut. Pengaruh positif dana pihak ketiga pada penyaluran kredit juga di dukung oleh penelitian sebelumnya yang di lakukan oleh (Murdiyanto, 2012), (Wahab, 2015), (Putra \& Rustariyuni, 2015), (Khasanah \& Meiranto, 2015) dan (Sutasari et al., 2018). Berdasarkan penjelasan tersebut di atas, maka hipotesis pertama dalam penelitian ini adalah:

\section{H1 : Diduga Dana Pihak Ketiga (DPK) berpengaruh terhadap Penyaluran Kredit}

\section{Pengaruh Capital Adequacy Ratio (CAR) terhadap Penyaluran Kredit}

$C A R$ merupakan rasio yang di gunakan untuk mengukur kecukupan modal bank, yaitu kemampuan bank dalam pembiayaan aktivitas kegiatan usahanya dengan kepemilikan modal yang di miliki (Fahmi, 2014). Menurut (Bridges et al., 2014) dan (Abdul Karim et al., 2014) menyatakan bahwa pemenuhan persyaratan Tingkat modal minimum yang baik maka BPR dapat memberikan volume pinjaman yang lebih besar dan dapat memastikan dana yang cukup untuk mengantisipasi dari kerugian tak terduga atau guncangan yang merugikan.

Maka tinggi nya CAR dapat membuat bank berani untuk memberikan kredit yang lebih besar kepada nasabah. Hasil tersebut juga di dukung oleh penelitian terdahulu yang di lakukan oleh (Khasanah \& Meiranto, 2015) yang menyatakan bahwa CAR memiliki pengaruh positif terhadap penyaluran kredit. Berdasarkan penjelasan tersebut di atas, maka hipotesis kedua dalam penelitian ini adalah:

\section{H2 : Diduga Capital Adequacy Ratio (CAR) berpengaruh terhadap Penyaluran Kredit}

\section{Pengaruh Loan to Deposit Ratio (LDR) terhadap Penyaluran Kredit}

Dalam rasio, LDR menjadi indikator inti untuk risiko ketidakcocokan suatu likuiditas sebab rasio tersebut mengukur kecukupan pinjaman dengan pendanaan yang stabil (Van den End, 2016). Peningkatan pertumbuhan pinjaman yang dominan akan meningkatkan rasio $L D R$, karena LDR di ukur dengan membandingkan jumlah kredit yang di salurkan dengan jumlah deposit yang di himpun dan dimiliki bank (Fahmi, 2014).

Maka dengan meningkat nya rasio LDR dapat menunjukkan bahwa dana yang dimiliki suatu bank telah di gunakan secara maksimal dalam penyaluran kredit (Adnana et al., 2016). Pengaruh positif $L D R$ pada penyaluran kredit juga di dukung oleh penelitian sebelumnya yang di lakukan oleh (Khasanah \& Meiranto, 2015) dan (Adnana et al., 2016). Berdasarkan penjelasan tersebut di atas, maka hipotesis ketiga dalam penelitian ini adalah:

\section{H3 : Diduga Loan to Deposit Ratio (LDR) berpengaruh terhadap Penyaluran Kredit}




\section{Pengaruh Non Performing Loan terhadap Penyaluran Kredit}

Rasio NPL merupakan rasio yang di gunakan bank dalam mengukur risiko dari penyaluran kredit dengan membandingkan jumlah kredit bermasalah dengan jumlah kredit yang di salurkan (Fahmi, 2014).

Menurut (Katriani \& Dewi, 2012), tinggi nya kredit yang disalurkan kepada masyarakat dapat menimbulkan risiko kredit macet yang tinggi. Hal tersebut di sebabkan karena banyak bank yang melakukan kelonggaran mengenai standar kredit pada pemberian kredit sehingga kredit yang di salurkan kepada debitur yang kebanyakan dapat di katakan tidak kompeten dalam melakukan pembayaran (Amin et al., 2019). Hasil tersebut juga di dukung oleh penelitian terdahulu yang di lakukan oleh (Khasanah \& Meiranto, 2015) yang menyatakan bahwa NPL memiliki pengaruh positif terhadap penyaluran kredit. Berdasarkan penjelasan tersebut di atas, maka hipotesis keempat dalam penelitian ini adalah:

\section{H4 : Diduga Non Performing Loan (NPL) berpengaruh terhadap Penyaluran Kredit}

\section{Pengaruh BI Rate terhadap Penyaluran Kredit}

Bank Indonesia (BI) Rate merupakan suku bunga acuan yang di keluarkan menurut kebijakan Bank Indonesia. Penetapan BI rate yang lebih tinggi akan mendorong bank untuk meningkatkan tingkat bunga pinjaman kepada debitur, Sedangkan penetapan BI rate yang lebih rendah akan mendorong bank untuk menurunkan tingkat bunga pinjaman kepada debitur.

Menurut (Sutasari et al., 2018) perubahan Bl rate secara tidak langsung berpengaruh terhadap penyaluran kredit, hal tersebut di sebabkan karena perubahan tingkat suku bunga acuan $\mathrm{BI}$ rate akan berpengaruh terhadap keputusan Lembaga Penjamin Simpanan (LPS) terhadap perubahan tingkat bunga penjaminan. dari penurunan tingkat bunga penjaminan yang di keluarkan oleh LPS akan menurunkan tingkat bunga simpanan pada bank serta membuat cost of fund pada bank akan menurun dan dari penurunan cost of fund tersebut membuat bank ikut menurunkan suku bunga kreditnya, hal tersebut dapat meningkatkan minat masyarakat untuk meminjam kredit. Hasil tersebut juga di dukung oleh penelitian terdahulu yang di lakukan oleh (Ichwani \& Dewi, 2019) dan (Wahab, 2015) yang menyatakan bahwa BI rate memiliki pengaruh negatif terhadap penyaluran kredit. Berdasarkan penjelasan tersebut di atas maka hipotesis kelima dalam penelitian ini adalah:

H5 : Diduga BI Rate berpengaruh terhadap Penyaluran Kredit.

\section{METODE PENELITIAN}

\section{Jenis dan Sumber Data Penelitian}

Dalam penelitian ini menggunakan data sekunder yang merupakan data yang sudah tersedia pada suatu media dan tidak didapatkan langsung dari sumber pertama. Dalam penelitian ini, dokumentasi data sekunder Dana Pihak Ketiga (DPK), Capital Adequacy Ratio (CAR), Loan to Deposit Ratio (LDR), Non Performing Loan (NPL) dan Penyaluran Kredit diambil dari Laporan Keuangan Tahunan periode tahun 2014 - 2018 yang di publikasikan oleh Otoritas Jasa Keuangan. Sedangkan data sekunder BI Rate di ambil dari suku bunga acuan yang di publikasikan oleh Bank Indonesia (BI) setiap akhir tahun dalam periode tahun 2014 - 2018.

\section{Metode Analisis dan Hipotesis Penelitian}

Penelitian ini menggunakan metode analisis regresi linear berganda. Metode analisis data tersebut bertujuan untuk menguji seberapa besar pengaruh lima variabel independen terhadap 
satu variabel dependen. namun sebelum melakukan pengujian hipotesis tersebut, terlebih dahulu dilakukan uji statistik deskriptif dan uji asumsi klasik. Pengolahan data penelitian dalam metode analisis ini di bantu dengan menggunakan program SPSS versi 26 (Statistical Package for Social Sciences). Adapun analisis statistik yang digunakan adalah analisis statistik deskriptif yang dapat memberikan gambaran suatu ukuran data yang digunakan untuk melihat seberapa besar kecenderungan data memusat pada nilai tertentu, sehingga menjadikan sebuah informasi yang lebih jelas dan mudah untuk dipahami. Menurut (J.Supranto, 2016), Analisis dalam penelitian ini dapat digunakan untuk menghitung nilai minimum, nilai maksimum, rata-rata, dan standard deviasi yang dihasilkan dari variabel penelitian. Selanjutnya dilakukan uji Outlier, yaitu jika suatu kasus atau data yang menyimpang terlalu jauh dari data yang lainnya karena memiliki karakteristik unik dalam suatu rangkaian data (J.Supranto, 2016). Menurut (Umar, 2019) Uji outliers dapat dilakukan dengan menggunakan program SPSS, yaitu dengan memilih menu Casewise Diagnostics, data dikategorikan sebagai data outlier jika memiliki nilai absolut dari studentized residual $>3$. Untuk menguji kualitas data, agar memenuhi syarat yang ditentukan maka perlu dilakukan beberapa pengujian asumsi klasik (Purnomo, 2016) yang terdiri dari Uji normalitas merupakan uji yang bertujuan untuk menguji apakah nilai residual suatu sampel yang di hasilkan dari regresi sudah berdistribusi normal atau tidak (Purnomo, 2016). Pengujian normalitas data dapat menggunakan metode One Sample Kolmogorov-Smirnov dan metode grafik dalam program SPSS. Selanjutnya uji multikolinearitas digunakan untuk menguji apakah dalam model regresi ditemukan ada atau tidaknya korelasi antara variabel bebas (Purnomo, 2016). Untuk mendeteksi ada tidaknya multikolinieritas dapat dilihat dari besaran Variance Inflation Factor (VIF) dan Tolerance. Menurut (Purnomo, 2016) Pedoman suatu model regresi yang bebas multikolinieritas adalah mempunyai angka tolerance lebih dari 0,1 dan batas VIF tidak lebih dari 10. Kemudian pengujian autokorelasi merupakan korelasi antara anggota observasi yang disusun menurut waktu atau tempat (Purnomo, 2016). Pada prosedur pendeteksian masalah autokolerasi dapat di gunakan besaran Durbin-Waston untuk memeriksa ada tidaknya autokolerasi, menurut (Sunyoto, 2016) Pengambilan keputusan pada uji Durbin watson sebagai berikut:

- Jika DW <-2, maka terjadi autokorelasi positif.

- Jika $-2<\mathrm{DW}<2$, maka tidak terjadi autokorelasi.

- Jika DW > 2, maka terjadi autokorelasi negatif.

Dan yang terakhir pengujian Heterokedastisitas adalah varian residual yang tidak sama pada semua pengamatan di dalam model regresi (Purnomo, 2016). Menurut (Purnomo, 2016) dan (Sunyoto, 2016), uji heteroskedastisitas dilakukan dengan menggunakan metode grafik scatter plot dengan bantuan software SPSS. Dasar kriteria nya dalam pengambilan keputusan yaitu:

- Jika ada pola tertentu, seperti titik-titik yang ada membentuk suatu pola tertentu yang teratur (bergelombang, melebar kemudian menyempit), maka terjadi heteroskedastisitas.

- Jika tidak ada pola yang jelas, seperti titik-titik menyebar di atas dan di bawah angka 0 pada sumbu $Y$, maka tidak terjadi heteroskedastisitas.

Lebih lanjut, analisis regresi linier berganda digunakan untuk mengetahui pengaruh atau hubungan secara linear antara dua atau lebih variabel independen dengan satu variabel dependen (Purnomo, 2016). Persamaan yang digunakan untuk menguji hipotesis dalam penelitian ini adalah sebagai berikut:

$$
Y=a+b_{1} X_{1}+b_{2} X_{2}+b_{3} X_{3}+b_{4} X_{4}+b_{5} X_{5}+e
$$




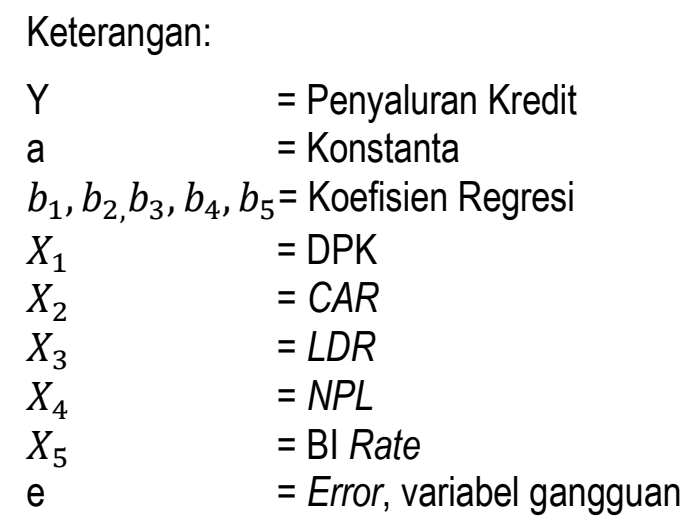

Kemudian koefisien determinasi $\left(\mathrm{R}^{2}\right)$ pada intinya mengukur seberapa jauh kemampuan model atau persentase sumbangan pengaruh variabel independen dalam menerangkan variasi variabel dependen (Purnomo, 2016). Nilai $\mathrm{R}^{2}$ yang kecil berarti kemampuan variabel-variabel independen dalam menjelaskan variasi variabel dependen amat terbatas. Hipotesis diuji dengan Uji statistik $\mathrm{F}$ bertujuan untuk mengetahui apakah semua variabel bebas yang digunakan dalam model regresi secara bersama-sama berpengaruh terhadap satu variabel terikat (Purnomo, 2016). Menurut (Purnomo, 2016) Dasar pengambilan keputusannya adalah:

- Jika $F$ hitung $<F$ tabel atau jika nilai Sig $F>0,05$, maka secara simultan variabel bebas tidak berpengaruh terhadap variabel terikat.

- Jika $F$ hitung $>F$ tabel atau jika nilai Sig $F<0,05$, maka secara simultan variabel bebas berpengaruh terhadap variabel terikat.

Uji hipotesis yang kedua adalah uji statistik T diperlukan untuk mengetahui pengaruh masingmasing variabel independen terhadap variabel dependen (Purnomo, 2016). Menurut (Purnomo, 2016) Pengambilan keputusan mengenai penerimaan atau penolakan hipotesis dapat didasarkan pada kriteria sebagai berikut:

- Jika $\mathrm{T}$ hitung < T tabel atau jika nilai Sig $\mathrm{T}>0,05$, maka secara parsial variabel bebas tidak berpengaruh terhadap variabel terikat.

- Jika T hitung > T tabel atau jika nilai Sig $\mathrm{T}<0,05$, maka secara parsial variabel bebas berpengaruh terhadap variabel terikat

\section{Operasional variable penelitian}

Variabel-variabel dalam penelitian ini terdiri dari variabel bebas (independen) yang meliputi: Dana Pihak Ketiga (DPK) sebagai $X_{1}$ Capital Adequacy Ratio (CAR) sebagai $X_{2}$, Loan to Deposit Ratio (LDR) sebagai $X_{3}$, Non Performing Loan (NPL) sebagai $X_{4}$ dan BI Rate sebagai $X_{5}$. Sedangkan variabel terikat (dependen) adalah Penyaluran Kredit sebagai $Y$.

1. Dana Pihak Ketiga (DPK)

Dana Pihak Ketiga yaitu total dari simpanan tabungan dan deposito pada akhir periode yang di logaritma natural (Ln). (Fahmi, 2014)

2. Capital Adequacy Ratio (CAR)

$C A R=\frac{\text { Modal } B a n k}{\text { ATMR }} \times 100 \%$ pada akhir periode yang di nyatakan dalam persentase.

(Fahmi, 2014) 
3. Loan to Deposit Ratio (LDR)

$L D R=\frac{\text { Total Kredit }}{D P K+\text { modal int } i} \times 100 \%$ pada akhir periode yang di nyatakan dalam persentase. (Fahmi, 2014) \& (Fitri \& Marlius, 2019)

4. Non Performing Loan (NPL)

$N P L=\frac{\text { Total Kredit Bermasalah }-P P A P}{\text { Total Kredit }} \times 100 \%$ pada akhir periode yang di nyatakan dalam persentase. (POJK No.15/POJK.03/2017)

5. BI Rate

Tingkat suku bunga acuan pada akhir periode yang di nyatakan dalam persentase.

(Bank Indonesia)

6. Penyaluran kredit

Tingkat suku bunga acuan pada akhir periode yang di nyatakan dalam persentase.

(Bank Indonesia)

\section{HASIL DAN PEMBAHASAN}

\section{Hasil Penelitian}

Langkah pertama adalah dengan melakukan pengujian statistik deskriptif, dan hasilnya ditunjukkan oleh tabel di bawah ini antara lain nilai minimum, maksimum, mean dan standar deviasi untuk masing-masing data setiap variabel.

\section{Tabel 1 Hasil statistik deskriptif}

\begin{tabular}{lcrrrr}
\hline & N & Minimum & Maksimum & Mean & Std. Deviation \\
\hline Kredit_Ln & 105 & 16,74 & 20,85 & 18,3979 & 0,78791 \\
DPK_Ln & 105 & 16,66 & 20,88 & 18,4584 & 0,83084 \\
CAR & 105 & 9,00 & 62,97 & 21,5141 & 10,85523 \\
LDR & 105 & 58,94 & 94,45 & 79,4374 & 7,56882 \\
NPL & 105 & 0,00 & 20,78 & 3,7136 & 3,4810 \\
BI Rate & 105 & 4,25 & 7,75 & 6,0500 & 1,41566 \\
Valid N & 105 & & & & \\
\hline
\end{tabular}

Sumber : Hasil output SPSS 26, (data diolah, 2020)

Hasil olah data uji outlier dapat dilihat sebagai berikut:

Tabel 2 Hasil Uji Outlier

\begin{tabular}{rcrrr}
\hline Case Number & Std Residual & \multicolumn{1}{c}{ Kredit_Ln } & Predicted Value & Residual \\
\hline 76 & 4,666 & 18,62 & 18,3025 & 0,32252 \\
77 & 3,456 & 18,84 & 18,4825 & 0,35468 \\
78 & 4,031 & 18,96 & 18,5492 & 0,41371 \\
79 & 3,371 & 18,89 & 18,5438 & 0,34598 \\
80 & 3,768 & 18,85 & 18,4652 & 0,38675 \\
\hline
\end{tabular}

Sumber : Hasil output SPSS 26, (data diolah, 2020)

Dari hasil uji Casewise Diagnostics di atas terdapat 5 data outlier yang harus di keluarkan dari sampel penelitian, karena kelima data tersebut memiliki nilai studentized residual lebih dari 3 
yaitu data ke-76 $=4,666$, data ke- $77=3,456$, data ke-78 $=4,031$, data ke-79 $=3,371$ dan data ke-76 $=3,768$.

Hasil-hasil Uji Asumsi Klasik terdiri atas:

Uji normalitas yang ditunjukkan oleh tabel dan gambar berikut ini.

Tabel 3 Hasil uji one sample kolmogorov-smirnov

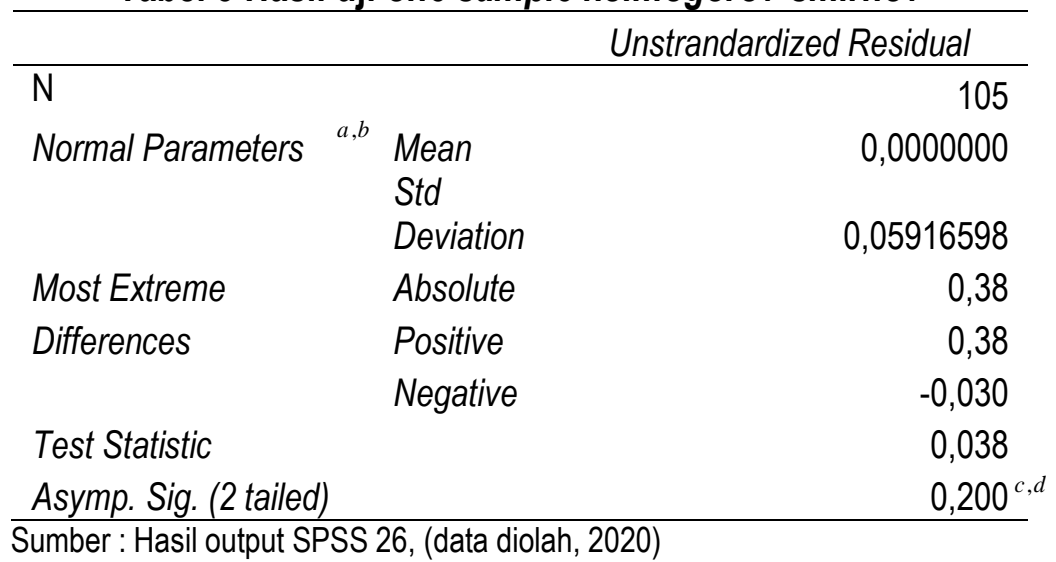

Berdasarkan tabel di atas, dapat diketahui bahwa jumlah sampel yang dimasukan dalam pengujian ini adalah 105 data. Nilai signifikan nya Asymp. Sig. (2-tailed) sebesar 0,200 c,d >0,05 yang berarti data residual berdistribusi normal.

Uji

\section{Gambar 1 Hasil Uji normal P-P plot of regression standardized}

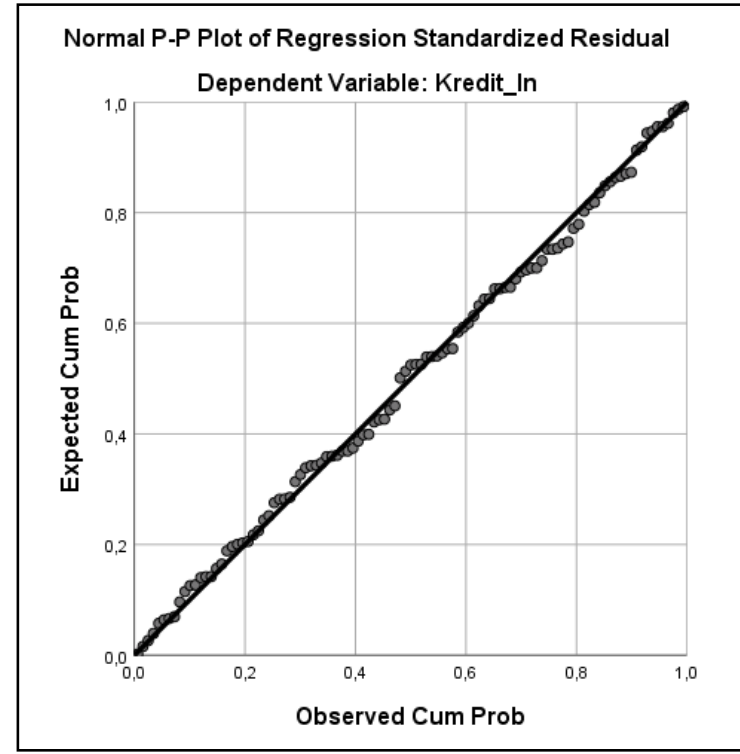

Sumber : Hasil output SPSS 26, (data diolah, 2020)

Dari grafik di atas dapat di simpulkan bahwa nilai residual terdistribusi secara normal, dimana pada gambar $P$-P plot Regrssion Standardized tersebut titik-titik nilai residual yang ada pada tabel alurnya mengikuti garis diagonal yang menunjukkan tingkat normalitas nilai-nilai residual yang ada.

Hasil olah Uji Multikolinieritas dapat dilihat sebagai berikut: 
Tabel 4 Hasil Uji Variance Inflation Factor (VIF) \& Tolerance

\begin{tabular}{lrr}
\hline \multicolumn{1}{c}{ Model } & Collinearity Statistics \\
\hline DPK_Ln & Tolerance & VIF \\
CAR & 0,675 & 1,48 \\
LDR & 0,611 & 1,637 \\
NPL & 0,879 & 1,138 \\
BI Rate & 0,924 & 1,082 \\
Sumber $:$ Hasil output SPSS 26, (data diolah, 2020) & 0,798 & 1,253 \\
\hline
\end{tabular}

Hasil perhitungan nilai Tolerance pada variabel $D P K=0,675, C A R=0,611, L D R=0,879$, $N P L=0,924$ dan $B I$ Rate $=0,798$ lebih dari 0,1 dan nilai VIF pada variabel $D P K=1,480, C A R=$ $1,637, L D R=1,138, N P L=1,082$ dan $B I$ Rate $=1,253$ lebih kecil dari 10 maka tidak terdapat multikolinearitas diantara variabel kredit sehingga asumsi multikoliniearitas terpenuhi.

Hasil olah Uji Autokorelasi dapat dilihat dibawah ini:

Tabel 5 Hasil uji durbin Watson

\begin{tabular}{lll}
\hline Model & Durbin-Watson & \\
\hline 1 & 1,000
\end{tabular}

Sumber : Hasil output SPSS 26, (data diolah, 2020)

Berdasarkan tabel di atas, diketahui bahwa nilai D-W adalah 1,000, ini berarti bahwa nilai Durbin-Watson berada diantara -2 sampai 2, hal tersebut menjelaskan bahwa tidak terdapat autokorelasi.

Hasil olah Uji heteroskedastisitas dapat dilihat pada grafik sebagai berikut:

Grafik 1 Hasil uji scatter plot

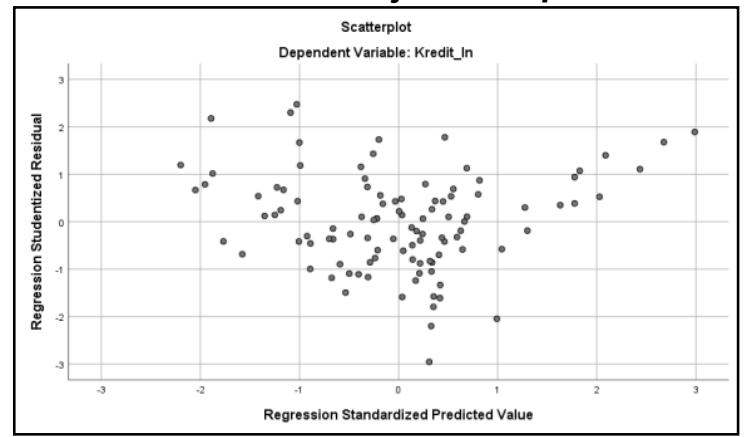

Sumber : Hasil output SPSS 26, (data diolah, 2020)

Dari grafik Scatterplot di atas terlihat bahwa:

- titik-titik menyebar secara acak serta tersebar baik di atas mapun di bawah angka 0 pada sumbu $Y$,

- titik-titik tidak membentuk suatu pola tertentu yang teratur, maka dapat di simpulkan tidak terjadi heteroskedastisitas.

Hasil olah Uji Regresi Linear Berganda dapat dilihat sebagai berikut: 
Tabel 6 Hasil Uji Regresi Linear Berganda

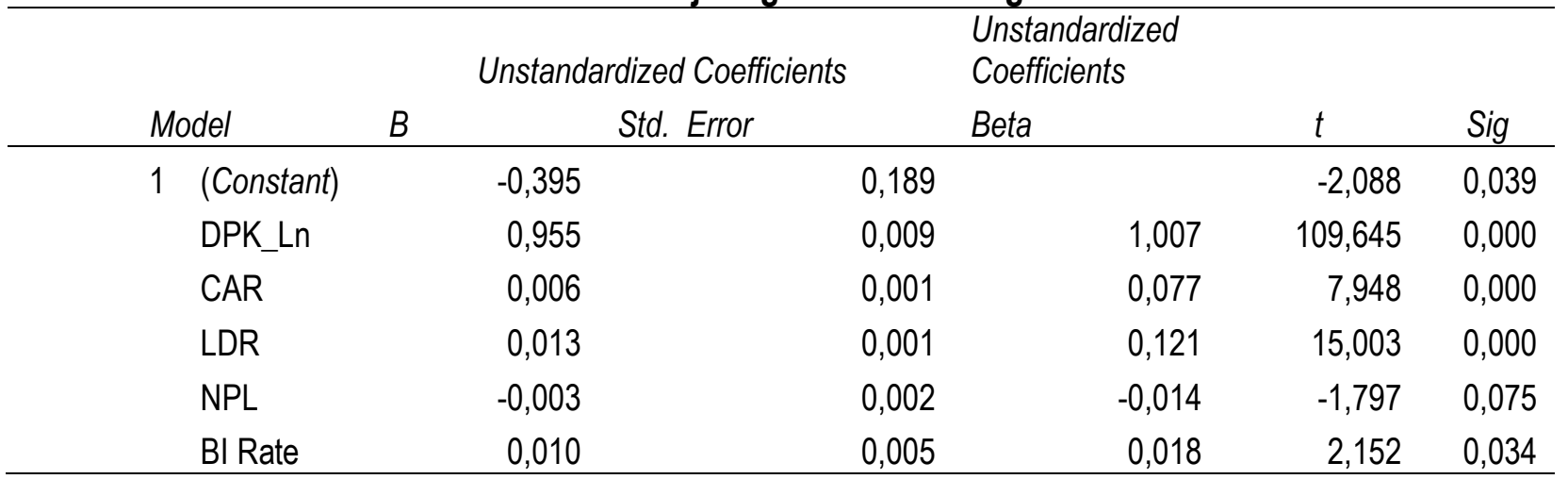

Sumber : Hasil output SPSS 26, (data diolah, 2020)

Dari perhitungan regresi diatas maka dapat dibentuk persamaan sebagai berikut:

$$
Y=-0,395+0,955 X_{1}+0,006 X_{2}+0,013 X_{3}-0.003 X_{4}+0.010 X_{5}+e
$$

Hasil olah Koefisien determinasi $\left(R^{2}\right)$ dapat dilihat sebagai berikut:

Tabel 7 Hasil Uji Koefisien Determinasi $\left(\mathbf{R}^{2}\right)$

\begin{tabular}{lrrrr}
\hline Model & $R$ & $R$ Square & $\begin{array}{r}\text { Adjusted } R \\
\text { Square }\end{array}$ & Std. Error of the Estimate \\
\hline 1 & $0,997^{a}$ & 0,994 & 0,994 & 0,06064
\end{tabular}

Sumber : Hasil output SPSS 26, (data diolah, 2020)

Dari tabel di atas diperoleh angka koefisien determinasi $\left(R^{2}\right)$ sebesar 0,994 . Hal ini berarti bahwa $99,4 \%$ variasi Yield to Maturity (YTM) dapat dijelaskan oleh variasi dari kelima variabel independen yaitu DPK, CAR, LDR, NPL dan BI Rate. Sedangkan sisanya 0,6\% dijelaskan oleh faktor atau variabel yang lain diluar model regresi.

Uji Hipotesis masing-masing ditunjukkan oleh hasil dari uji $\mathrm{F}$ dan uji T yang dilakukan dalam penelitian ini dapat dilihat sebagai berikut:

Tabel 8 Hasil Uji Signifikansi Simultan

\begin{tabular}{|c|c|c|c|c|c|c|}
\hline & Model & $\begin{array}{l}\text { Sum of } \\
\text { Squares }\end{array}$ & $d f$ & Mean Square & $F$ & Sig. \\
\hline \multirow[t]{3}{*}{1} & Regression & 64,199 & 5,000 & 12,840 & 3491,556 & $0,000^{b}$ \\
\hline & Residual & 0,364 & 99,000 & 0,004 & & \\
\hline & Total & 64,564 & 104,000 & & & \\
\hline
\end{tabular}

Sumber : Hasil output SPSS 26, (data diolah, 2020)

Berdasarkan hasil uji signifikansi simultan (Uji Statistik F) pada Tabel 4.6, diperoleh nilai $F$ hitung sebesar 34961,556 lebih besar dari nilai $F$ tabel sebesar 2.31 dan tingkat signifikan 0,000 lebih kecil dari tingkat alfa yang digunakan, yaitu 0,05 (5\%). Maka dari tabel diatas ini memberikan penjelasan bahwa variabel DPK, CAR, LDR, NPL dan BI Rate terbukti memiliki pengaruh yang signifikan secara bersama-sama terhadap kredit.

Hasil dari uji T pada data yang dilakukan dalam penelitian ini dapat dilihat sebagai berikut: 
Tabel 9 Hasil Uji Signifikansi Individual

\section{Pembahasan}

\begin{tabular}{crl} 
Model & \multicolumn{1}{c}{$\mathrm{t}$} & Sig. \\
\hline 1 (Constant) & $-2,088$ & 0,039 \\
DPK_Ln & 109,645 & 0,000 \\
CAR & 7,948 & 0,000 \\
LDR & 15,003 & 0,000 \\
NPL & $-1,797$ & 0,075 \\
BI Rate & 2,152 & 0,034 \\
\hline Sumber : Hasil output SPSS 26, (data diolah, 2020)
\end{tabular}

\section{Pengaruh Dana Pihak Ketiga terhadap Penyaluran Kredit}

Dari hasil uji statistik pada variabel DPK terhadap penyaluran kredit terdapat nilai T hitung sebesar 109,645 lebih besar dari T tabel sebesar 1.984 dengan nilai signifikansi 0,000 dimana nilai ini lebih kecil dari tingkat alfa yang digunakan yaitu 0,05 serta memiliki nilai koefisien regresi positif sebesar 0,955, maka dapat disimpulkan bahwa dana pihak ketiga (DPK) memiliki pengaruh positif secara parsial terhadap penyaluran kredit

\section{Pengaruh Capital Adequacy Ratio terhadap Penyaluran Kredit}

Dari hasil uji statistik pada variabel CAR terhadap penyaluran kredit terdapat nilai $\mathrm{T}$ hitung sebesar 7,948 lebih besar dari $T$ tabel sebesar 1.984 dengan nilai signifikansi 0,000 dimana nilai ini lebih kecil dari tingkat alfa yang digunakan yaitu 0,05 serta memiliki nilai koefisien regresi positif sebesar 0.006, maka dapat disimpulkan bahwa Capital Adequacy Ratio (CAR) memiliki pengaruh positif secara parsial terhadap penyaluran kredit

\section{Pengaruh Loan to Deposit Ratio terhadap Penyaluran Kredit}

Dari hasil uji statistik pada variabel $L D R$ terhadap penyaluran kredit terdapat nilai $T$ hitung sebesar 15,003 lebih besar dari T tabel sebesar 1.984 dengan nilai signifikansi 0,000 dimana nilai ini lebih kecil dari tingkat alfa yang digunakan yaitu 0,05 serta memiliki nilai koefisien regresi positif sebesar 0.013 , maka dapat disimpulkan bahwa Loan to Deposit Ratio (LDR) memiliki pengaruh positif secara parsial terhadap penyaluran kredit.

\section{Pengaruh Non Performing Loan terhadap Penyaluran Kredit}

Dari hasil uji statistik pada variabel NPL terhadap Penyaluran kredit terdapat nilai T hitung sebesar -1,797 lebih kecil dari T tabel sebesar 1.984 dengan nilai signifikansi 0,075 dimana nilai ini lebih besar dari tingkat alfa yang digunakan yaitu 0,05 serta memiliki nilai koefisien regresi negatif sebesar -0.003 , maka dapat disimpulkan bahwa Non Performing Loan (NPL) tidak memiliki pengaruh secara parsial terhadap Penyaluran Kredit

\section{Pengaruh BI Rate terhadap Penyaluran Kredit}

Dari hasil uji statistik pada variabel $\mathrm{BI}$ Rate terhadap penyaluran kredit terdapat nilai T hitung sebesar 2,152 lebih besar dari T tabel sebesar 1.984 dengan nilai signifikansi 0,034 dimana nilai ini lebih kecil dari tingkat alfa yang digunakan yaitu 0,05 serta memiliki nilai koefisien regresi negatif sebesar 0.010 , maka dapat disimpulkan bahwa BI Rate memiliki pengaruh positif secara parsial terhadap penyaluran kredit. Hasil tersebut dikarenakan BPR dalam memberikan suku bunga kredit kepada tiap - tiap nasabah tidak sama persis dengan suku bunga dari BI rate, tetapi 
dari hasil kesepakatan di awal peminjaman seperti mempertimbangkan jangka waktu, kualitas jaminan dan hubungan yang baik antara calon nasabah dengan pihak bank.

\section{Pengaruh Dana Pihak Ketiga, Capital Adequacy Ratio, Loan to Deposit Ratio, Non} Performing Loan dan BI Rate terhadap penyaluran kredit

Dari hasil uji statistik pada variabel Dana Pihak Ketiga (DPK), Capital Adequacy Ratio (CAR), Loan to Deposit Ratio (LDR), Non Performing Loan (NPL) \& BI Rate terhadap penyaluran kredit terdapat nilai $F$ hitung sebesar 3491,556 lebih besar dari nilai $F$ tabel sebesar 2.31 dan tingkat signifikan 0,000 lebih kecil dari tingkat alfa yang digunakan, yaitu 0,05 (5\%). Maka dapat disimpulkan bahwa Dana Pihak Ketiga (DPK), Capital Adequacy Ratio (CAR), Loan to Deposit Ratio (LDR), Non Performing Loan (NPL) \& BI Rate memiliki pengaruh secara simultan terhadap penyaluran kredit.

\section{REKOMENDASI DAN KEBIJAKAN}

Berdasarkan hasil analisis dan kesimpulan dalam penelitian ini, maka dapat disampaikan beberapa rekomendasi dan kebijakan sebagai berikut:

1. Bagi peneliti selanjutnya dapat menambah variabel independent sesuai dengan keadaan perekenomian yang terjadi saat ini, serta dalam Penggunaan periode penelitian dapat di perpanjang dan dalam pemilihan sampel dapat menggunakan kriteria lain, sehingga hasil yang di peroleh akan lebih lebih akurat dan signifikan.

2. Bagi pihak bank di harapkan dapat di jadikan sebagai bahan evaluasi dan analisis dalam memperhatikan faktor-faktor yang dapat mempengaruhi pada penghimpunan dan penyaluran kredit kepada masyarakat.

\section{DAFTAR PUSTAKA}

\section{Pengaruh BI Rate terhadap Penyaluran Kredit}

Dari hasil uji statistik pada variabel BI Rate terhadap penyaluran kredit terdapat nilai T hitung sebesar 2,152 lebih besar dari T tabel sebesar 1.984 dengan nilai signifikansi 0,034 dimana nilai ini lebih kecil dari tingkat alfa yang digunakan yaitu 0,05 serta memiliki nilai koefisien regresi negatif sebesar 0.010 , maka dapat disimpulkan bahwa $\mathrm{BI}$ Rate memiliki pengaruh positif secara parsial terhadap penyaluran kredit. Hasil tersebut dikarenakan BPR dalam memberikan suku bunga kredit kepada tiap - tiap nasabah tidak sama persis dengan suku bunga dari BI rate, tetapi dari hasil kesepakatan di awal peminjaman seperti mempertimbangkan jangka waktu, kualitas jaminan dan hubungan yang baik antara calon nasabah dengan pihak bank.

\section{Pengaruh Dana Pihak Ketiga, Capital Adequacy Ratio, Loan to Deposit Ratio, Non Performing Loan dan BI Rate terhadap penyaluran kredit}

Dari hasil uji statistik pada variabel Dana Pihak Ketiga (DPK), Capital Adequacy Ratio (CAR), Loan to Deposit Ratio (LDR), Non Performing Loan (NPL) \& BI Rate terhadap penyaluran kredit terdapat nilai $F$ hitung sebesar 3491,556 lebih besar dari nilai $F$ tabel sebesar 2.31 dan tingkat signifikan 0,000 lebih kecil dari tingkat alfa yang digunakan, yaitu 0,05 (5\%). Maka dapat disimpulkan bahwa Dana Pihak Ketiga (DPK), Capital Adequacy Ratio (CAR), Loan to Deposit Ratio (LDR), Non Performing Loan (NPL) \& BI Rate memiliki pengaruh secara simultan terhadap penyaluran kredit.

\section{REKOMENDASI DAN KEBIJAKAN}

Berdasarkan hasil analisis dan kesimpulan dalam penelitian ini, maka dapat disampaikan beberapa rekomendasi dan kebijakan sebagai berikut: 
3. Bagi peneliti selanjutnya dapat menambah variabel independent sesuai dengan keadaan perekenomian yang terjadi saat ini, serta dalam Penggunaan periode penelitian dapat di perpanjang dan dalam pemilihan sampel dapat menggunakan kriteria lain, sehingga hasil yang di peroleh akan lebih lebih akurat dan signifikan.

4. Bagi pihak bank di harapkan dapat di jadikan sebagai bahan evaluasi dan analisis dalam memperhatikan faktor-faktor yang dapat mempengaruhi pada penghimpunan dan penyaluran kredit kepada masyarakat. 


\section{DAFTAR PUSTAKA}

Abdul Karim, M., Hassan, M. K., Hassan, T., \& Mohamad, S. (2014). Capital adequacy and lending and deposit behaviors of conventional and Islamic banks. Pacific Basin Finance Journal, 28, 58-75. https://doi.org/10.1016/j.pacfin.2013.11.002

Adnana, Ridwan, \& Fildzahc. (2016). Pengaruh Ukuran Bank, Dana Pihak Ketiga, Capital Adequacy Ratio, dan Loan To Deposit Ratio Terhadap Penyaluran Kredit Pada Perusahaan Perbankan yang Terdaftar Di Bursa Efek Indonesia Tahun 2011-2015. Jurnal Dinamika Akuntansi Dan Bisnis, 3(2), 49-64. https://doi.org/10.24815/jdab.v3i2.5386

Amin, K. A. A., Madi, M., \& Madi, R. A. (2019). Pengaruh Makro Ekonomi dan Fundamental Bank Terhadap Non Performing Loan (Studi Pada Bank Umum Swasta Nasional Devisa yang Terdaftar Di Bursa Efek Indonesia Periode 2012-2016). https://doi.org/10.31227/osf.io/kgw98

Bridges, J., Gregory, D., Nielsen, M., Pezzini, S., Radia, A., \& Spaltro, M. (2014). The Impact of Capital Requirements on Bank Lending. SSRN Electronic Journal, (486). https://doi.org/10.2139/ssrn.2388773

Fahmi, I. (2014). Pengantar Perbankan dan Teori Aplikasi. Bandung: Alfabeta.

Fitri, H. Y., \& Marlius, D. (2019). Analisis Rasio Likuiditas Pada PT Bank Pengkreditan Rakyat (BPR) Lengayang. 1-11. https://doi.org/10.31219/osf.io/bcs73

Haryanto, S. B., \& Widyarti, E. T. (2017). Analisis Pengaruh NIM, NPL, BOPO, BI Rate dan CAR Terhadap Penyaluran Kredit Bank Umum Go Public Periode 2012-2016. Diponegoro Journal of Management, 6(4), 1-11.

Ichwani, T., \& Dewi, R. S. (2019). Pengaruh Perubahan BI Rate menjadi BI 7 Day Reserve Reporate Terhadap Jumlah Kredit UMKM. Quality Jurnal Manajemen Dan Akutansi, 10(29), 259-270.

J.Supranto. (2016a). Statistik Teori \& Aplikasi Edisi 8 Jilid 1 (8th ed.; A. Maulana, ed.). Jakarta: Penerbit Erlangga.

J.Supranto. (2016b). Statistik Teori \& Aplikasi Edisi 8 Jilid 2 (8th ed.; A. Maulana \& S. Saat, eds.). Jakarta: Penerbit Erlangga.

Katriani, R., \& Dewi, A. S. (2012). Analisis tingkat kesehatan bank dan pertumbuham laba pada perusahaan sektor perbankan di Indonesia. https://doi.org/10.31227/osf.io/9eqkc

Khasanah, U., \& Meiranto, W. (2015). Analisis Pengaruh Faktor Internal dan Eksternal Terhadap Volume Penyaluran Kredit Perbankan. Jurusan Akuntansi Fakultas Ekonomika Dan Bisnis Universitas Diponegoro, 4(2), 1-13.

Murdiyanto, A. (2012). Faktor-Faktor Yang Berpengaruh Dalam Penentuan Penyaluran Kredit Perbankan (Studi Pada Bank Umum Di Indonesia Periode Tahun 2006 - 2011). CBAM-FE Unissula, 1(1), 61-74.

Ozili, P. K. (2019). Non-performing loans and financial development: new evidence. Journal of Risk Finance, 20(1), 59-81. https://doi.org/10.1108/JRF-07-2017-0112

Purnomo, R. A. (2016). Analisis Statistik Ekonomi dan Bisnis Dengan SPSS (2nd ed.; P. C. Ambarwati, ed.). Ponorogo: Ponorogo: WADE Group.

Putra, I. G. O. P., \& Rustariyuni, S. D. (2015). Pengaruh DPK, BI rate, dan NPL terhadap Penyaluran Kredit Modal Kerja pada BPR di Provinsi Bali Tahun 2009-2014. E-Jurnal Ekonomi Pembangunan Universitas Udayana, 451-464. Retrieved from https://ojs.unud.ac.id/index.php/eep/article/view/12129

Situmorang, B. (2017). Pengaruh Peringkat Obligasi, Debt to Equity Ratio dan Ukuran Perusahaan terhadap Yield to Maturity Obligasi Korporasi dengan Tingkat Suku Bunga SBI sebagai Variabel Moderating. Jurnal Terapan Manajemen dan Bisnis, 3(1), 42-58. 
Sunyoto, D. (2016). Metodologi Penelitian Akuntansi. Bandung: Refika Aditama.

Sutasari, N. L. P. B., Aryawan, G., \& Purnami, A. A. S. (2018). Pengaruh BI Rate dan Jumlah Simpanan Masyarakat terhadap Penyaluran Kredit pada Bank Umum Pemerintah di Bali Periode 2013.I-2017.IV. Warmadewa Economic Development Journal, 1(2), 68-77. https://doi.org/http://dx.doi.org/10.22225/wedj.1.2.1099.68-77

Umar, H. (2019). Metode riset manajemen perusahaan : langkah cepat dan tepat menyusun tesis dan disertasi. Jakarta: Gramedia Pustaka Utama.

Van den End, J. W. (2016). A macroprudential approach to address liquidity risk with the loan-todeposit ratio. European Journal of Finance, 22(3), 237-253. https://doi.org/10.1080/1351847X.2014.983137

Wahab, A. (2015). Pengaruh PDRB, Inflasi, Suku Bunga Bank Indonesia dan Dana Pihak Ketiga Terhadap Penyaluran Kredit Pada Bank-Bank Umum di Sulawesi Selatan. Economics, Social, and Development Studies, 2(1), 1-25. https://doi.org/10.24252/ecc.v2i1.1131

Otoritas Jasa Keuangan. (2015). Peraturan Otoritas Jasa Keuangan. No.33/POJK.03/2018.

Kualitas Aset Produktif dan Pembentukan Penyisihan Penghapusan Aset Produktif Bank Perkreditan Rakyat. 